Welch, Susan and John R. Hibbing. 1983. "What Do the New Ratings of Political Science Departments Measure?" PS 16: 532-540.

\section{Introducing the National Political Science Review}

\begin{abstract}
A new journal has hit the political science profession with the publication of the first volume of the National Political Science Review in February 1989. Published annually by the National Conference of Black Political Scientists, the NPSR includes scholarly research and commentary reflective of diverse interests and perspectives of scholars from various backgrounds and life experiences. According to Lucius Barker, NPSR editor and Gellhorn Professor of Public Affairs and Political Science at Washington University (St. Louis) the NPSR "represents an important step in the growth and development of the NCOBPS as a professional scholarly organization.
\end{abstract}

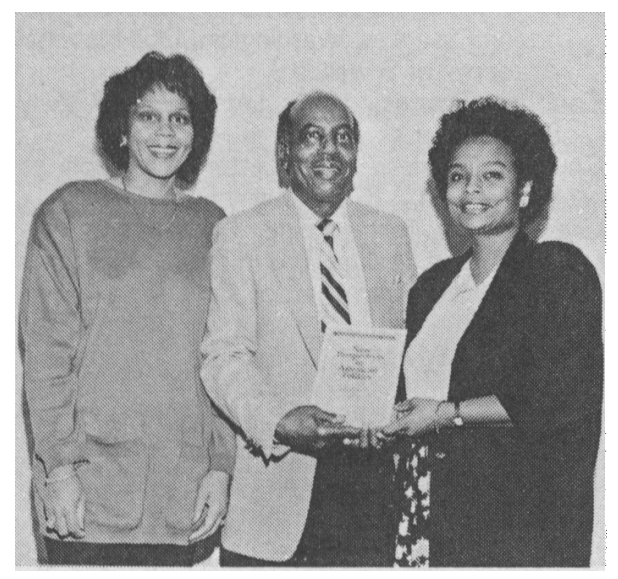

Paula D. McClain, book review editor, and Lucius J. Barker, editor, presents commemorative copy of the NPSR to Dianne Pinderhughes, president of the National Conference of Black Political Scientists at its annual meeting held in Baton Rouge, LA, March 15-18, 1989.
Barker observes that "the rich diversity of interests and scholarship represented in the NPSR is clearly reflected in the coverage and treatment of topics that should appeal to a wide readership. "Among the major feature articles, for example, are contributions by Stuart Clark, a Ph.D. candidate at Yale on "Liberalism and Black Political Thought," and an article by Robert H. Salisbury, Souers Professor of American Politics at Washington University (St. Louis) on "Political Movements in American Politics." Additionally, a number of scholars offer varied commentaries on two special symposia: "The IranContra Affair" and a bicentennial assessment of "Black Americans and The Constitution.'

The NPSR also includes a major book review section that uses a variety of formats in which to view recent and current literature: a Book Forum with review essays on selected books dealing with "Jesse Jackson and Presidential Politics;" four extensive bibliographic essays surveying literature on Black Politics, Women and Politics, Chicano Politics, and American Indians; and regular book reviews.

The NPSR welcomes contributions on any important research problem in political science but is particularly interested in theoretical/empirical research that focuses on politics and policies that advantage or disadvantage groups or individuals by reasons of race, ethnicity, sex, or other such factors.

Contributions should be no longer than 30 typewritten pages double-spaced, and should follow guidelines of the Chicago Manual of Style. An abstract of no more than 150 words should appear on a separate cover sheet. Five copies of each manuscript should be sent to Lucius J. Barker, Editor, National Political Science Review, Department of Political Science, Washington University, St. Louis, MO. 63130.

Requests for book reviews should be sent to Paula D. McClain, Book Review Editor, School of Public Affairs, Arizona State University, Tempe, AZ 85387. Inquiries about standing orders for the NPSR should be addressed to Transaction Publishers, Rutgers-The State University, New Brunswick, N.j. 08903. 